\title{
Governance Innovations and Population Data Recording in Southeast Aceh Regency
}

\author{
Muhamad Husein Maruapey ${ }^{1}$ \\ ${ }^{1}$ Study Program of Public Administration, Djuanda University, Bogor, INDONESIA
}

(Received July 29, 2019; Accepted December 21, 2019; Published December 26, 2019)

\begin{abstract}
Population data management involves many complex activities of different types of organizations, stakeholders, and knowledge. Innovation is essential in improving the efficiency of the public sector. Governance innovations will give the consequences of the success of innovation itself. Good governance is a reflection of the innovation strategy of a government administration process. The focus of this research is to investigate the phenomenon of innovation in the management of population data and documents in Southeast Aceh regency. The qualitative method with phenomenological analysis is used to explain and identify how the phenomenon occurs. The data collection is done inductively by having interviews, discussions, and participatory observation. The triangulation approach is used to explain empirical and secondary data. The results of this study found that the management of innovation should be supported by various supporting policies and the leadership capacity of policy maker. Community participation and cross-border cooperation also contributed to the management of innovation. Innovation is also an immediate need today to deliver excellent public services by the government.
\end{abstract}

Keywords: governance, innovation, public services, public administration, population

JEL Classification: H70, O32, R58

\section{INTRODUCTION}

The population of Indonesia is the world's 4th largest with 264 million people after China, India, and the United States (Population Reference Bureau, 2017). It makes the government of Indonesia is obliged to have accurate population data. Such data are essential to map development planning formulation, public services provision, budget allocation, the number of poor, the development of democracy and the rule of law. It has an interest in the identification of needs to formulate any publicly strategic policy.

Data management and legal documents are necessary to organize and manage data in a modern way. Law Number 24 the Year 2013 concerning Population Administration requires structuring, issuance of documents and

\footnotetext{
${ }^{*}$ Corresponding author email: Maruapey.husein@gmail.com ISSN 2615-6075 online; ISSN 2615-6946 print @UWG Press, 2019

OJS http://publishing-widyagama.ac.id/ejournalv2/index.php/jsed/
}

demographic data accurately. Professional population administration services meet standards in terms of information technology, dynamic, orderly and non-discriminatory to address population problems. The government should appropriately manage population administration through the relevant ministry.

The use of technology in data recording and residence documents should lead to efficiency and certainty of service settlement. Making the residency documents are free and not littered with extortion and regulated in government policy. By January 2017, there were 21 thousand inhabitants of the Southeast Aceh regency that have not been registered in official data (Disdukcapil Southeast Aceh Regency, 2017).

One way of structuring in the issuance of population data documents is innovation. Innovation is a real need to improve the performance of the bureaucracy so that it becomes more effective (McHugh, O'Brien, \& Ramondt 2010). Innovation needs to be implemented and integrated into the system that guides the 
management mechanism and monitoring process in the long term (Klimentova, 2014). The innovation model associated with the population data and documents has also been carried out. For example, South Korea's government improved administrative efficiency and transparency of demographic data and contribute to the principles of good governance (Kim \& Cho, 2005).

Meanwhile, the regency government of Gunung Kidul implemented the use of an android touchscreen service containing information about various administration services. It accompanies the information media provision through face to face, local radio, booklets, leaflets, pamphlets, banners, and exhibitions. The government also actively goes to the villages to collect data, register and update population data. This is then administered in an orderly manner and compiled archives through an electronic system. (Disdukcapil Gunung Kidul, 2016). The problem of population data administration comes from expired family cards, data duplication and population data loss. (Kemenpan, 2016).

Managing innovation involves many complex activities of different kinds of bureaucratic activity in increasing innovation to achieve goals effectively and efficiently. The activity was at least include the elements of planning and decision-making, goalsetting, coordination, leadership, and development. Furthermore, the management of innovation can be pulled or pushed to adopt various forms of innovation based on the priority need. Some studies claim that the difficulties to innovate has led to the non-functioning of the bureaucracy (Hummel, 2015).

Within the scope of the government bureaucracy, innovation can minimize the problem of corruption, collusion and nepotism (Klarskov \& Nikolov, 2007), contribute to the performance and effectiveness of the organization (Damanpour \& Aravind, 2011). Within the scope of services, innovation is believed to improve the quality of services effectively and efficiently (Vries, Bekkers, and Hasselt, 2015), and maximize human resources competence and restore public confidence in the government (United Nations, 2006). The idea of innovation for government institutions is also regulated in the Law of the Republic of Indonesia
Number 23 the Year 2014 on Regional Government in Section 386 paragraph 1 of Article 21.

Innovation management needs to be managed in innovative ways. The Taiwan government has formulated a policy making process in certain sectors to always adjust to the national innovation system including research, technology, development, and innovation (Chung, 2011). This is to support the development of biotechnology in the pharmaceutical, agriculture and health sectors. The UK also runs innovation management through the formulation of low carbon energy development policies, including policy management, industrial development, and the empowerment of business actors (Thomas, 2015).

Scupola and Zanfei (2016) revealed that governance innovation requires the role and participation of innovation users to achieve greater inclusiveness. Innovations that are driven by the role of users will significantly increase the diffusion of innovations. Besides, the collaboration of various actors and the use of information technology influences the nature and intensity of the innovation use.

The concept of governance innovation contains new ideas, experiments, and practices that can help to achieve better coordination and more massive results (Moore \& Hartley, 2008; Anttiroiko, Bailey, \& Valkama, 2011; Scupola \& Zanfei, 2016), Governance innovation can promote public sector innovation capacity, which is often seen as an alternative and not as a compliment. Public administration theories such as new public service theory, administrative reform, contingency theory, innovation theory, institutional theory, governance theory (Anttiroiko, Bailey, \& Valkama, 2011; Torfing \& Triantafillou, 2016) show a positive correlation between forms of interactive governance and public sector innovation. Anttiroiko, Bailey, and Valkama (2011: 13) mention the concept of implementing governance innovations, such as the function of democracy, managerial, development and functions of government services.

This study focuses on investigating innovations in document management and population data in the regency of Southeast Aceh. The conceptual approach of Anttiroiko, Bailey and Valkama (2011) 
is used to explore innovative management mechanisms further.

\section{RESEARCH METHOD}

This research is a qualitative study using phenomenological analysis to identify, explain and describe how the phenomenon of innovation occurs. Data collection is done inductively, through interviews, discussions and participatory observation. In-depth interviews were conducted with 37 informants consisting of 23 policy actors, 10 residents, and 4 civil society groups. The informant has a background as an actor or follows events related to innovation in population governance. Policy actors are those in executive and legislative positions. Residents are community leaders representing several communities in 8 districts (Babussalam, Lawe Bulan, Deleng Pokhisen, Bambel, Semadam, Lawe Sigala-gala, Badr, Lawe Alas) in Southeast Aceh regency. Civil society consists of three NGO leaders and one academician.

The logical-phenomenological analysis is done based on the personal knowledge and subjectivity and emphasizes the importance of personal perspectives and interpretations (Groenewald, 2004). The phenomenological analysis is very useful in presenting people's experiences and perceptions to be able to describe or oppose structural and normative assumptions. Interpretation is carried out to confirm a theoretical basis, to inform support or oppose policies and actions. Giorgi (1997) provides guidance on steps to carry out the analysis of phenomenology, namely: (1) the phenomenological reduction, (2) description, and (3) searching for essences.

The description of innovative governance implementation in population data management is formulated through the theoretical concept approach of Anttiroiko, Bailey and Valkama (2011), which covers aspects of democracy, managerial, development and function of government services

\section{RESULT AND DISCUSSION}

Innovative governance in research explores population data management and innovation population documents in the regency of Southeast Aceh. It is then compared with experience elsewhere, developing arguments from the relevant scientific literature. This research is expected to contribute to insights on how to manage innovation in innovative ways. This discussion is directed by a conceptual foundation through democratic, managerial, development and government service function factors

\section{Democracy}

Democracy in the view of Anttiroiko, Bailey and Valkama (2011) refers to the mechanism of the political process between the executive and the legislature to produce policy formulation. The two parties work together, formulate priorities, determine indicators for program preparation, and endorse the formulation of development policies and programs. The agreement is then carried out by regional and sectoral leaders according to their authority.

The policy also reflects the commitment to develop innovation governance so that the implementation is accountable, transparent and participatory. It requires supportive leadership and conducive political relations (Cerne, Jaklic, \& Skerlavaj, 2013; Lewis, Richard, and Klijn, 2017).

The success of innovation should also be supported by various parties such as human resources from various parties, collaboration, community participation, and civil society to encourage the dynamics and utilization of governance innovation.

Southeast Aceh Qanun Regulation No. 80 of 2013 as a derivative of Law 24/2013, gives direction to the regional population offices paying special attention to population administration issues. However, this has not been implemented well. During the 2011-2017 period, budget allocations were prioritized for road infrastructure development projects and other sectors. Meanwhile, population administration has not become a focus of attention so it still keeps the problem. These problems include improper office buildings, lots of data duplication, complicated services and bribery practices in population administration services. It is well known that population administration services are one of the most basic public services beside health and education services. 
Life in leadership is still oriented toward client and patron relationships. This began with the election process of regional leaders who were dominated by certain groups (Aspinall \& Sukmajati, 2015). This pattern is also accompanied by the initial practice of bribery and political money, as well as certain promises to achieve power. Leadership is not based on the objective criteria regarding competence or vision to improve community welfare.

The study of Sjahrir, Kis-Katos, and Schulze (2013) found that leadership behavior will adapt to various pressures and demands from internal and external parties. The political leadership behavior always displays the dominance of the role of the character and background, and only a small proportion sees competence. This can have an impact on elevating the interests of certain groups. Bureaucracy is also used for certain groups to carry out their interests, not to serve the public interest.

The Office of Population and Civil Registration of Southeast Aceh Regency is responsible for the functions of population administration services, data management and population registration. Service performance has not been optimal in providing public services. Regional leadership is aware of the problem. Problems that repeatedly occur from year to year without any comprehensive solution. Leadership does not show competence, empathy and conception to solve problems.

The population administration sector is seen as not contributing benefits to certain parties, compared to physical or infrastructure development such as irrigation, roads, bridges or certain building constructions.

The Padang Pariaman Regency Government provides positive experiences in population administration development. The government considers population administration to be one of the top priorities. The Legislature and Executive work together to take steps to change, promote innovation, and carry out population administration programs to the field (Disdukcapil Padang Pariaman, 2017). Regional leaders appear to be dominant in making changes to a series of programs through the Regional Work Units (SKPK). The policy steps are followed by decision making that accurately follows needs, dimensions of policies that operate effectively, and works in a system. Decision making also considers a set of principles that are generally distinguished from the principles of rationality and politics. The output of the process provides the best alternative decision that is ready to be implemented.

\section{Management of Innovation}

The success of innovation management is determined by leadership. The leader needs to increase his knowledge and competence so that he understand how to apply innovation in policy (Borins, 2002). The leader exercises managerial ability and knowledge to carry out planning, goal setting, operational methods and control to achieve goals. Transformational leadership has the competence and ability to transform values into organizational goals. Transformational leaders will utilize innovation to engineer organizational management in achieving the goals. DuBrin (2006) divides managerial skills, among others, technical skills, interpersonal skills, conceptual skills, diagnostic skills, and political skills. Managerial functions require conceptual and analytical skills to develop innovation and ensure the innovation cycle runs. Its function is also obliged to ensure the service process runs well.

The Office of Population and Civil Registration of Southeast Aceh Regency has run a mobile service car innovation and call center. Mobile service car visits directly among the people who need services. However, the presence of mobile cars received an inadequate response from the community due to coordination problems between the regency office and the local area. Regency officials often do not know about the presence of mobile cars in their areas. As a result, regency officials are unable to provide information to the community. The itinerary of mobile service car visits is not well coordinated. In addition, the mobile service car should be directed to areas where the level of data recording and population administration document indicators is low.

Call center innovation can establish interactive communication to serve the needs and complaints of the public. This innovation is done well and integrated with the function of a mobile car. However, it is still found obstacles in coordination between the call center in the regency office and 
the mobile car. Another weakness is the limited resources in the office center of population administration.

In March 2018, the population administration office developed service innovation by opening a regional hospital service office. The goal is to record the birth of a baby, make a birth certificate, and update changes in family card data. This innovation helps the community.

Innovations in population data management have been carried out by the DKI Jakarta provincial government. The Jakarta government made an innovation in the Si Shaman (Integrated Population System Document), which is to open service outlets in hospitals. Newborns get 6 services at once, namely birth certificates, NIK, KK, Birth Act, KIA, and membership ID from the BPJS (Director General of Civil Registration, 2018). This is a real innovation model that integrates up to 6 services from a population data system.

The scope of innovation should anticipate the process of changing services, from manual to electronic, traditional to modern, integration of several stages into one service, to provide good public services. In the new concept of public service, employees should work publicly and accurately, and also respond to the needs of "customers" quickly and efficiently (Denhardt \& Denhardt, 2015). The concept of service in the innovation process refers to the new service products including elements of technology, engineering, or skills. The diversity of services is identified about nature and innovation in order to provide public services responsibly. At this point, leadership and managerial roles are urgently needed including taking a role in controlling.

\section{Development of Innovation}

The development of innovation requires cooperation involving various parties. Collaboration with the private sector to invite participation in developing and socializing innovations. The private sector will also strengthen the duties and functions of population administration services.

Collaboration with Radio, local TV or local news portals will help to accelerate and broaden the dissemination of information on population administration services. The collaboration will increase public participation to oversee the implementation of innovations and to receive input from NGOs, academics or other community groups to develop innovation. Increased collaboration with institutions use population data such as the Health office, BPJS or KPU (General Election Commission). Public participation in the development of innovation is very important because the public is the user or object of the service (United Nations, 2006; Moore and Hartley, 2008). Input from the community becomes consideration for the development of further innovation.

Community participation in the Southeast Aceh Regency in the development of innovation is still low. The community is still apathetic to contribute to the development. When the dissemination of demographic data governance applications was carried out, most people did not respond positively. However, when people require services, such as hospital treatment, social security cards, new student enrollments in schools, and job registrations, the awareness of the importance of population records will emerge.

Efforts to increase public participation are still limited to the regency, district and village government officials. This effort is usually carried out in village development planning meetings (musrenbang) and other official forums. Beyond that, there are no breakthroughs that can increase public participation. These opportunities can be done for example, when health services (posyandu) are carried out in the village, door-to-door friendship is used for the elderly and people with disabilities, or data collection of school-age children.

Government agencies that use population administration services play an essential role in the development of innovation. They have the same mission in serving the wider community, so it becomes a necessity for cooperation. They will welcome among innovations or accept the results of innovations according to the government regulations. They often provide feedback and follow up the innovation development.

The development of population administration management innovation can follow the example of Padang Pariaman, Klungkung, Badung, Situbondo, and Tanah Datar Regency. These areas have the 
innovation to be directly presented in the community. Officials utilize mobile services using motorbikes or cars. Population administration services can be presented in remote areas to public places, in good coordination between institutions in implementing population administration. Simply, when the government makes it easy for people, people automatically respond with increased participation. This means that when innovation is beneficial for users and recipients, innovation will show its benefits.

In the conception of modern governance, community participation is a requirement (Bryson et al, 2012). The concept of public administration states that public participation is an interaction between the public and administrators, to produce the effectiveness and efficiency of public policies and public services (Callahan, 2007). The decentralization process is fundamental as an innovative form of collaboration between the government and the community to produce decision making and support.

\section{Service Functions of Government}

The phenomenon of poor public services by bureaucracy is a serious concern. The number of public services at the local or regional level varies by country. In UK, public services in the region reached 85 percent for the private sector (Erridge, 2009).

In Indonesia, the number of public services at the regional level is not as large as in UK, and the innovation is still low. Raadschelders (2003) states that the low level of public services comes from the allocation of budget use, closed bureaucracy, management with traditional characteristics, and poor coordination.

Innovation can help in improving the function of public services. Technology helps transparency and outreach, increases public access, simplifies procedures, facilitates coordination, and helps control. It can be done through radio, television, the internet or social media. Innovation also helps in increasing the role and the existence of the government. The government is here to serve and protect the needs of the community, especially health services, education and population administration.
The use of technology in terms of recording data and citizenship documents in Southeast Aceh regency has not shown optimal results. Not all of the 16 districts in Southeast Aceh Regency are connected to the Office of the Population and Civil Registry servers. Four districts do not have cellular networks due to geographical conditions that are far from the regency capital. It makes it impossible to make a KTP (ID Card) record.

The KTP procedure is to record the KTP-el in the district, and the residents take the KTP in the regency office of the Population and Civil Registry. This innovation is for efficiency reasons and to avoid bribery by district officials. However, the problem still arises because the distance from the homes of residents to the office of the population office is relatively far, so there is an additional transportation fee for district personnel to take KTP. Another problem is that the internet is down, so electronic data transmissions fail.

Internet shut down constraints disrupt other population administration services at the district office. Law No. 24 of 2013, Article 8 point 3 explains that the Civil Registration Service at the regency level is carried out by the UPT Implementing Agency with authority to issue a Civil Registry Deed. The delegation of authority from local leaders to the regency has never been done and will force the community to continue paying to update the document. The proposed procurement of the internet networks in the regency has been submitted. However, since 2015, the internet network has never been realized, citing the lack of local government budgets.

The regional government should find a solution so that the community is not burdened with additional costs for completing population registration. It might be the cause of the community not recording population documents. It is ironic because it forces the public to register, while the government does not provide adequate facilities.

The experience of the Klungkung regency government in Bali province provides examples of solutions to the above problems. They fielded special officers on motorbikes to reach out to do KTP data recording for people with special needs and especially in remote areas. This innovation is a 
derivative of the action program Gema Santi (Special and Innovative Community Movement) initiated directly by local government leaders.

The concept of public service states that the government should adopt new ways of service and increase efficiency. In addition, support is needed so that policy decisions can be implemented (Osborne \& Brown, 2011). Institutions with good public service performance cause an increase in satisfaction, which in turn will lead to an increase in public trust in government (Cooper \& Reinagel, 2015; Denhardt \& Denhardt, 2015). Therefore, public services remain an issue that continues to be fixed by the government.

The implementation of innovation management cannot stand alone. Many factors influence innovation management such as a conducive political process between the legislature and executive, budgetary resource agreements, and planning and decision making in policies. Managerial ability, competence, and cooperation in managing innovation have positive impacts on the development of innovation (Anttiroiko, Bailey, \& Valkama, 2011).

Evaluation is an important step to oversee innovation management. The best way to start with a simple criterion is to determine whether an idea, method or implementation of innovation works correctly. Evaluations can use criteria related to budget, human resources, and policies. Evaluation criteria should consider that failure and success of innovation are learning and long-term. It should be noted that innovation should consider reasons for effectiveness, financial viability, proper management, and excellent public service delivery.

\section{CONCLUSION AND SUGGESTION}

Public awareness of domicile and population administration documents is essential. That awareness is also the responsibility of the government as a public service apparatus. Therefore, local governments can make various innovations to track and oversee population administration. One of the government's efforts is to increase the capacity, capability, integrity in carrying out its duties. Innovative governance always involves changes in government management systems in public services. Innovation will change management systems that cross organizational boundaries, strengthen and improve organizational performance. When public services governance changes the right way, innovation can be made for the benefit of users in general. Thus, a balance between various governance paradigms will spur the production of public innovations, bring a new thing, and better solutions.

This research has the following implications. First, the implementation of innovation by local governments is not easy to do. Furthermore, innovation needs to be managed in innovative ways too. Innovation will be able to show results when innovation is supported by policy, resources, managerial and infrastructure. Second, it is the need for transformational leadership. Transformational leadership has the competence and ability to transform competencies into organizational goals or values. Transformational leaders will understand the strategic character of innovation, and utilize innovation to engineer organizational management. The aspects of planning, management, direction and control are designed to be innovative in order to deliver innovative services to the public.

The research contributes to insight knowledge and empirical experience regarding innovation management in innovative ways. It provides a framework for managing innovation in the public sector.

\section{REFERENCES}

Anttiroiko, A. V., Bailey, S. J., \& Valkama, P. (2011). Innovations in public governance in the Western world. Innovation and the Public Sector, 15, 1-22. https://doi.org/10.3233/9781-60750-727-7-1

Aspinall, E., \& Sukmajati, M. (2016). Electoral Dynamics in Indonesia: Money Politics, Patronage and Clientelism at the Grassroots. NUS Press. Retrieved from https://books.google.co.id/books?id=pi3jCwAAQ $\underline{B A J}$

Borins, S. (2002). Leadership and innovation in the public sector. Leadership \& Organization Development Journal, 23(8), 467-476. https://doi.org/10.1108/01437730210449357

Bryson, J. M., Quick, K. S., Slotterback, C. S., \& Crosby, B. C. (2013). Designing Public 
Participation Processes. Public Administration Review, 73(1), 23-34. https://doi.org/10.1111/j.15406210.2012.02678.x

Callahan, K. (2007). Citizen Participation: Models and Methods. International Journal of Public Administration, 30(11), 1179-1196. https://doi.org/10.1080/01900690701225366

Černe, M., Jaklič, M., \& Škerlavaj, M. (2013). Authentic leadership, creativity, and innovation: A multilevel perspective. Leadership, 9(1), 6385. https://doi.org/10.1177/1742715012455130

Chung, C. -. (2011). Government, Governance and the Development of the Innovation Systems: The Example of the Taiwanese Biotechnology and Related Sectoral Policies. University of Manchester. Manchester, UK. Retrieved from https://www.research.manchester.ac.uk/portal/ en/theses/government-governance-and-thedevelopment-of-the-innovation-systems-theexample-of-the-taiwanese-biotechnology-andrelated-sectoral-policies(504024b2-cb76-4624a31b-3572e4a7fa57).html

Cooper, C. A., \& Reinagel, T. P. (2017). The Limits of Public Service Motivation: Confidence in Government Institutions Among Public Servants. Administration and Society, 49(9), 1297-1317.

https://doi.org/10.1177/0095399715581039

Damanpour, F., \& Aravind, D. (2012). Managerial Innovation: Conceptions, Processes, and Antecedents. Management and Organization Review, 8(2), 423-454. https://doi.org/10.1111/j.17408784.2011.00233.x

De Vries, H., Bekkers, V., \& Tummers, L. (2016). Innovation in the public sector: A systematic review and future research agenda. Public Administration, 94(1), 146-166. https://doi.org/10.1111/padm.12209

Denhardt, J. V., \& Denhardt, R. B. (2015). The New Public Service Revisited. Public Administration Review, 75(5), 664-672. https://doi.org/10.1111/puar.12347

Disdukcapil Gunung Kidul. (2016 11 23). Innovation services in the Department of Population and Civil Registration Gunung Kidul Regency. Retrieved March 12, 2018, from http://dukcapil.gunungkidulkab.go.id/inovasipelayanan-di-dinas-kependudukan-danpencatatan-sipil-kabupaten-gunungkidul/
Disdukcapil Pariaman. (2017, December 29). Won the Green Zone, Disdukcapil Padang Pariaman Continues Improve Quality Services. Retrieved April 17, 2018, from http://dukcapil.padangpariamankab.go.id/index. php?option=com content\&view $=$ article\&id $=187$ :zonahijau\&catid=88: berita\&Itemid $=2327$

Disdukcapil Southeast Aceh Regency. (2017). Recording Data Report Residents of Southeast Aceh Regency Year 2017. Kutacane: Department of Population and Civil Registration Southeast Aceh Regency.

DuBrin, A. J. (2011). Essentials of Management (9th ed.). Cengage Learning. Retrieved from https://books.google.co.id/books?id=PRWOozV $\underline{\text { bsekC }}$

Erridge, A. (2009). Contracting for Public Services. In A. G. Bovaird, T. Bovaird, \& E. Löffler (Eds.), Public Management and Governance (Second Edition, pp. 95-108). Routledge. Retrieved from https://books.google.co.id/books?id=wjuz75AiV WQC

Giorgi, A. (1997). The theory, practice, and evaluation of the phenomenological method as a qualitative research procedure. Journal of Phenomenological Psychology, 28(2), 235-260. https://doi.org/10.1163/156916297X00103

Groenewald, T. (2004). A Phenomenological Research Design Illustrated. International Journal of Qualitative Methods, 3(1), 42-55. https://doi.org/10.1177/160940690400300104

Hummel, R. P. (2014). The Bureaucratic Experience: The Post-Modern Challenge: The Post-Modern Challenge. Taylor \& Francis. Retrieved from https://books.google.co.id/books?id=yj7fBQAAQ BA]

Kemenpan. (2016, March 14). Ministry PANRB Set Top 99 Public Service Innovation 2016. Retrieved on April 11, 2018, from https://www.menpan.go.id/berita-terkini/4516kementerian-panrb-tetapkan-top-99-inovasipelayanan-publik-2016

Kim, S., \& Cho, K. (2005). Achieving administrative transparency through information systems: A case study in the Seoul metropolitan government. In Lecture Notes in Computer Science (Vol. 3591, pp. 113-123). https://doi.org/10.1007/11545156 11

Klareskov, V., \& Nikolov, D. (2007). Eleven Innovations in Governance in the Middle East, North Africa, and Western Balkans. In 
Innovations in Governance in the Middle East, North Africa, and Western Balkans: Making Governments Work Better in the Mediterranean Region (p. 247). New York: UN. Retrieved from https://books.google.co.id/books?id=FoB5$\underline{\text { TUtaCoC }}$

Klimentova, S. (2014). Innovation in the public sector: Is it measurable? Studies in Managerial and Financial Accounting, 28, 289-315. https://doi.org/10.1108/S1479351220140000028021

Lewis, J. M., Ricard, L. M., \& Klijn, E. H. (2018). How innovation drivers, networking and leadership shape public sector innovation capacity. International Review of Administrative Sciences, 84(2), 288-307. https://doi.org/10.1177/0020852317694085

McHugh, M., O'brien, G., \& Ramondt, J. (2001). Finding an alternative to bureaucratic models of organization in the public sector. Public Money and Management, 21(1), 35-42. https://doi.org/10.1111/1467-9302.00246

Moore, M., \& Hartley, J. (2008). Innovations in governance. Public Management Review, 10(1), 3-20. https://doi.org/10.1080/14719030701763161

Osborne, S. P., \& Brown, L. (2011). Innovation, public policy and public services delivery in the UK. The word that would be king? Public Administration, 89(4), 1335-1350. https://doi.org/10.1111/j.14679299.2011.01932.x

Raadschelders, J. C. N. (2015). Government: A Public Administration Perspective: A Public
Administration Perspective. Taylor \& Francis. Retrieved from https://books.google.co.id/books?id=yfbqBgAA QBAJ

Scupola, A., \& Zanfei, A. (2016). Governance and innovation in public sector services: The case of the digital library. Government Information Quarterly, 33(2), 237-249. https://doi.org/10.1016/j.giq.2016.04.005

Sjahrir, B. S., Kis-Katos, K., \& Schulze, G. G. (2013). Political budget cycles in Indonesia at the district level. Economics Letters, 120(2), 342-345. https://doi.org/10.1016/j.econlet.2013.05.007

Thomas, G. (2015). Constructing The Hydrogen Fuel Cell Community: A Case Study of Networked Governance Innovation. University of Birmingham, Birmingham, UK. Retrieved from https://etheses.bham.ac.uk/id/eprint/6630/

Torfing, J., \& Triantafillou, P. (2016). Enhancing Public Innovation by Transforming Public Governance. In J. Torfing \& P. Triantafillou (Eds.), Enhancing Public Innovation by Transforming Public Governance (pp. 1-32). Cambridge University Press. https://doi.org/10.1017/CBO9781316105337

United Nations. (2006). Innovations in Governance and Public Administration: Replicating what Works. (G. Bertucci, A. Alberti, \& V. Klareskov, Eds.). New York: United Nations, Dept. of Economic and Social Affairs. Retrieved from https://books.google.co.id/books?id=dFsu13fvsf gC 